\title{
Repressed Sexual Modernity: A Case Study of Herbert Giles' (1845 - 1935) Rendition of Pu Songling's Strange Stories from a Chinese Studio (1880) IN THE LATE QING
}

\author{
Wing Bo Anna TSO \\ The Open University of Hong Kong, Hong Kong \\ atso@ouhk.edu.hk
}

\begin{abstract}
Translation studies in English and Chinese has long been of great interest to academics. Yet, Chinese scholars who have translation training and linguistic expertise are often found to "give excessive attention to listing facts and probing linguistic matters, to the neglect of the cultural and contextual considerations that have given rise to translation in China in the first place" (Lin, 2002, p. 170). Much emphasis has been placed on translation strategies, while translation "in connection with power and patronage" (Lefereve, 1992, p. 10) is overlooked, leaving "existing ideology" or "existing poetics" (Lefereve, 1992, p. 10), such as gender unexplored. In light of this, this paper attempts to take the literary and cultural approach and focus on examining the gender ideologies in Pu Songling's Strange Stories from a Chinese Studio (1740) and Herbert Giles' English rendition (1880). By comparing the source and target texts, the paper reveals that in many of Pu Songling's stories, spirit-free love and sexual pleasure are celebrated. A witty parody of the imitative structures of gender can be found in Pu Songling's "Painted Skin" too. Unfortunately, to a large extent, such transgressive gender views are repressed in Giles' English rendition.
\end{abstract}

Keywords: carnivalesque; Pu Songling; repressed sexual modernity; sexual autonomy and diversity; translation studies

\section{Povzetek}

Prevodoslovne razprave iz in $v$ angleščino oz. kitajščino so $v$ akademskem svetu že dolgo aktualne. Vseeno pa še vedno prevladuje mnenje, da kitajski prevajalci, ki so sicer opravili prevajalsko uvajanje in imajo tudi jezikoslovno znanje, vse preveč pozornosti namenjajo nizanju dejstev in jezikoslovnim problemom in tako zanemarjajo kulturne in kontekstualne pomisleke, ki so v osnovi spodbudili prevajanja na Kitajskem (Lin, 2002, str. 170). Velik poudarek je na strategijah prevajanja, medtem ko je spregledano prevajanje, ki je "povezano z močjo in pokroviteljstvom" (Lefereve, 1992, str. 10). S tem so spregledane in ostajajo neraziskane obstoječe ideologije, kot je na primer vprašanje spolov, ter poetika (Lefereve, 1992). $V$ tem kontekstu se tokratna raziskava posveča proučitvi ideologij o spolih v Pu Songlingovem delu Strange Stories from a Chinese Studio (1740) in angleški prevod Herberta Gilesa (1880). Primerjava izvornega in prevedenega teksta razkriva, da sta v veliki večini zgodb avtorja Pu Songlinga močno opevana neduhovna ljubezen in seksualno zadovoljstvo. 
Duhovito parodijo imitativnih struktur spolov najdemo tudi v Pu Songlingovem delu »Barvna polt«. $\mathrm{Na}$ žalost pa Gilesov prevod v angleščino v precejšnji meri zatre transgresivne poglede na spol.

Ključne besede: mesenost; Pu Songling; zatrta seksualna modernost; seksualna avtonomija in raznolikost, prevodoslovne razprave

\section{Introduction}

Inspired by the successful modernization of Japan, Chinese intellectuals in the late Qing felt a need for understanding Western culture, as well as the urgency for selfstrengthening. With fervent pursuits of modernity and civilization, Chinese scholars tried to modernize China by introducing the well-remembered Self-Strengthening Movement. Pioneer scholars such as Yan Fu (嚴復), Lin Shu (林紓), and Liang Qichao (梁啟超) translated a series of influential foreign works into Chinese, introducing Western modernity into China. By the late Qing, at least 615 full-length British and foreign books were translated to Chinese. The concepts of human rights, liberalism, feminism, together with the ideological representations of the 'New Woman', were all imported into China.

Meanwhile, British sinologists also felt that there was a need to study and translate Chinese literary texts. Among the many Chinese fictional works in circulation in the late Qing, Pu Songling's (蒲松齡) Strange Stories from a Chinese Studio 《聊齊志異》 attracted attention of western scholars. One possible reason could be that though $\mathrm{Pu}$ Songling published his masterpiece in the early Qing, the exploration of sexual diversity in his work, as well as the celebration of sexual autonomy, was in line with sexual modernity, one cornerstone of Western modernity. In 1880, Herbert Allen Giles (1845 - 1935) published his first English rendition of Strange Stories from a Chinese Studio. Since then, English readers from all over the world have been reading it, and publishers keep reprinting Giles' translated text till this day. Unfortunately, Giles was very conservative about introducing the carnivalesque essence in Pu Songling's stories into the English text. In this paper, I will discuss how the free-spirit attitude towards sexual autonomy and diversity in the source text is removed and altered in Giles' translation.

One main reason why this research study on gender ideology and translation has to be conducted is that more awareness towards the cultural paradigm should be raised in Chinese translation studies. In China's circle of translation studies, there has been an unhealthy and imbalanced inclination of studying, learning and teaching translation only through translation practice. While the translation training focuses a great deal on contrastive linguistics, the cultural perspective is often overlooked in translation classes. As Liu points out:

Chinese learners of translation have access only to practice-oriented translation techniques illustrated in a lot of context-free sentence translation examples. Such 
techniques are for example diction, conversion, amplification, omission, substitution, comparison, and inversion, all of which are restricted to language per se. This is a direct application in translation teaching of the achievement of contrastive linguistics (between English and Chinese).

Perhaps because the teaching of contrastive linguistics and translation methods is much more direct, straightforward and mechanical than the teaching of the cultural aspect of translation studies, a sizeable amount of translation scholars and teachers in China tend to take the easier path and leave the cultural and contextual elements in translation neglected and unexplored. Up till recent years, according to Zhong, China is still lagging behind in the field of translation studies, in particular regarding the development of translation theory:

Looking back over the history of translation of China, [...] it is hard to find a systematic translation theory to guide translation practice although there are prescriptive explanations of how to translate. By comparing this situation with the west, we find that the development of translation, and especially translation theory, is lagging in China although it is now a major translation user.

It is hoped that this paper can serve as a strong example highlighting the significance of studying translation through power relations and gender ideology in discourse. When it comes to translation studies, it is crucial to strike a balance between the linguistic perspective and the cultural perspective, alongside striving towards a balance between practice and theory.

For readers who cannot comprehend Pu Songling's original text in Chinese, John Minford's accurate and reliable English translation of Strange Stories from a Chinese Studio (2006), together with Tong and Minford's (1999) careful translation of "Miss Lian-Hsiang, the Fox Girl" (蓮香) are provided in the following translation analysis. Contrasted with Pu Songling's Chinese original version as well as Tong and Minford's faithful and scholarly English translated texts, the mistranslations and intentional alterations Giles made to his English translation shall come into sight.

\section{Free Love and Sexual Liberation in Pu Songling's Tales (1740)}

To the general public in the mid-Qing, sexual freedom and personal autonomy concerning marriage and reproductive choice, especially that of women, was unthinkable. The mid-Qing was a time when the majority of the Chinese women were still victims of the oppressive feudal system. Sex within heterosexual marriage was seen as the cornerstone of moral and social order. Widow chastity was the social norm, and widow chastity was widely accepted. The notion of Chinese mothers, wives and daughters enjoying sex for sheer sexual pleasure was out of the question. Who would have imagined that Pu Songling's Strange Stories from a Chinese Studio (1740) would 
go so far as to embrace the idea of sexual freedom and liberation for both men and women? Even for the leading reform-minded members in late-Qing China, the idea was disruptive, if not subversive. In the following excerpts from two tales, "Miss LianHsiang, the Fox Girl” (蓮香) and “Painted Wall” (畫壁), we can observe how Pu Songling allows both male and female protagonists (though many are spectres, foxes and ghosts) in his tales to enjoy free love and sexual pleasure with no guilty feelings and no necessary tie to marriage or to family.

\section{Excerpt One from “Miss Lian-Hsiang, the Fox Girl” (蓮香)}

\section{Source text}

The $26^{\text {th }}$ tale, from volume 2 :

一夕, 獨坐凝思, 一女子翩然入。

$$
\text { ... }
$$

年僅十五六, 享單袖垂髺, 風流秀曼, 行步之間，若還若往。

既而羅襦衿解, 儼然處子。女曰: 「妾 為情緣, 藏䓰之質, 一朝失守。不嫌鄙 陃，願常侍枕蓠。房中得無有人否？」

\section{Minford's English translation} (Tong \& Minford, 1999, p. 23):

But one evening when Sang was sitting alone lost in thought, another young lady came flitting in.

...

She was about fifteen or sixteen years of age, wore very full sleeves, and dressed her hair loosely after the fashion of unmarried girl. She had a graceful, sensuous manner and drifted across the room.

Then her silken robe was unloosed. In truth he found her to be a virgin. "Our love is fated," she said. "For this, I have given you the flower of my virginity. If you do not think me unworthy, I will gladly stay with you for ever and share your bed. Do you have another lover?"

As seen in the excerpt above, a young lady drifts into the studio of a young gentleman. What follows is, as Minford (2006) summarizes, that the "young gentleman finds her extraordinarily beautiful, undresses her, and with no delay they go to bed and make love" (Minford, 2006, xx). One night stand happens; female sexuality is naturally expressed, and in Pu Songling's tale, there is nothing shameful or wrong about nonmarital sexual activities. Although the mysterious young lady turns out to be a ghost, Pu Songling has approved of the maiden's freedom of sexual expression, a concept that has only been celebrated in recent decades even in the West. 


\section{Excerpt Two from “Painted Wall” (畫壁)}

\section{Source text}

The $6^{\text {th }}$ tale, from volume 1 :

東壁畫散花天女，內一垂髺者，拈花微

笑, 櫻唇欲動, 眼波將流。朱注目久,

不覺神搖意奪，恍然凝想。

\section{Minford's English translation}

(Minford, 2006, p. 23-24):

On the eastern wall was a painting of

Apsaras Scattering Flowers, beautiful fairylike beings, among whom Zhu noticed one maiden with unbound hair, a flower in her hand and a magical smiling face. Her lips seemed to move, and the light in her eyes rippled like water. Zhu stared at this maiden like a man transfixed, and was soon utterly transported by the vision.

$\cdots$

女回首，舉手中花，遙遥作招狀，乃趨

The maiden looked back and beckoned

之。舍內叔無人; 遽擁之, 亦不甚拒, 遂與狎好。既而閉戶去，囑勿咳，夜乃 復至, 如此二日。

\section{him on with the flower that she still held} in her hand. So he followed her into the pavilion, where they found themselves alone, and where with no delay he embraced her and, finding her to be far from unreceptive, proceeded to make love to her. Afterwards she left him and went away, closing the door behind her and bidding him not to make the slightest sound. That same night she returned, and so their liaison continued for a further two days.

In brief, what happens in the tale is that one day, a young man meets a beautiful woman. Mutually attracted to each other, the two lovers go to bed and make love on their first encounter. Although the male gaze is obvious in the narrative, Pu Songling's tale has made it clear to the readers that emotional love, sexual autonomy, and sexual pleasure for pleasure's sake can be experienced not just by a young man, but by a lady too. Sex is not just for procreation. On the contrary, it can be a celebration of the basic instinct and life force of humans. Likewise, love "outside of wedlock" and "free of obligation" is true, because couples "get together for no reason at all but love" (Wu, 1987, p. 178). This view again echoes individualism, "the most important value of Western civilization" (Golden, 2006, p. 17), which foreshadows the modern gender view.

\section{Sexual Repression in Giles' English Translation}

Had Pu Songling's Strange Stories from a Chinese Studio (1740) been faithfully translated into English at the turn of the century, it would have been a powerful 
Chinese text that enlightened the Western view on sex, marriage, and sexuality. Unfortunately, Herbert Giles' English translation in 1880 is a total disappointment. Not only has it not enriched the notion of sexual modernity, Giles hijacks Pu Songling's masterpiece and mixes ideological stereotypes of Victorian England into the source text, suppressing Pu's progressive ideas on sex, love and marriage.

Giles \& Minford's English Translations of “Miss Lian-Hsiang, the Fox Girl” (蓮香)

\begin{tabular}{l} 
Minford's English translation \\
(Minford, 2006, p. 23): \\
\hline But one evening when Sang was sitting \\
alone lost in thought, another young lady \\
came flitting in.
\end{tabular}

She was about fifteen or sixteen years of age, wore very full sleeves, and dressed her hair loosely after the fashion of unmarried girl. She had a graceful, sensuous manner and drifted across the room.

...

Then her silken robe was unloosed. In truth he found her to be a virgin. "Our love is fated," she said. "For this, I have given you the flower of my virginity. If you do not think me unworthy, I will gladly stay with you for ever and share your bed. Do you have another lover?"

\section{Giles' English translation}

(Giles, 1880, pp. 169-170):

But one evening when Sang was sitting alone expecting her, another young lady suddenly walked in.

...

She was about fifteen or sixteen years of age, wore very full sleeves, and dressed her hair after the fashion of unmarried girl, being otherwise very stylish-looking and refined, and apparently hesitating whether to go on or go back.

...

She then remarked that she intended to visit him pretty frequently, and hoped it would not inconvenience him.

Giles \& Minford's English Translations of “Painted Wall” (畫壁)

\section{Minford's English translation}

(Minford, 2006, pp. 23-24):

On the eastern wall was a painting of Apsaras Scattering Flowers, beautiful fairylike beings, among whom Zhu noticed one maiden with unbound hair, a flower in her hand and a magical smiling face. Her lips seemed to move, and the light in her eyes rippled like water. Zhu stared at this maiden like a man transfixed, and was soon utterly transported by the vision.

\section{Giles' English translation}

(Gilesm 1880, pp. 9-10):

On the east side were pictured a number of fairies, among whom was a young girl whose maiden tresses were not yet confined by the matron's knots. She was picking flowers and gently smiling, while her cherry lips seemed about to move, and the moisture of her eyes to overflow. Mr. Chu gazed at her for a long time without taking his eyes off, until at last he became unconscious of anything but the thoughts that were engrossing him. 
The maiden looked back and beckoned him on with the flower that she still held in her hand. So he followed her into the pavilion, where they found themselves alone, and where with no delay he embraced her and, finding her to be far from unreceptive, proceeded to make love to her. Afterwards she left him and went away, closing the door behind her and bidding him not to make the slightest sound. That same night she returned, and so their liaison continued for a further two days.
But the young lady, looking back, waved the flower she had in her hand as though beckoning him to come on. He accordingly entered and found nobody else within. Then they fell on their knees and worshipped heaven and earth together, and rose up as man and wife, after which the bride went away, bidding Mr. Chu keep quiet until she came back. This went on for a couple of days...

Compared with Minford's accurate translation, in Giles' version, all sexual activities of unmarried couples are censored. Occasionally, casual sex between lovers who are attracted to each other is replaced by a private wedding ceremony.

\section{Gender Boundary Violation in Pu Songling's “Painted Skin” (畫皮) (1740)}

Besides "Miss Lian-Hisang, the Fox Girl" and "Painted Wall", there are also multiple tales in Strange Stories from a Chinese Studio (1740) that problematize the naturalized gender stereotypes propagated in traditional Confucian values. For example, "The Male Concubine" (男妾), the $26^{\text {th }}$ tale of volume 11 , suggests bisexuality and queer erotic love. Likewise, another famous tale, "Painted Skin" (畫皮), the $40^{\text {th }}$ tale of volume 1 , also challenges the ideological gender stereotypes and puts forward a queer possibility unimaginable to many: what if the sexually appealing one is not a woman, but a sexy genderless creature?

The plot of "Painted Skin" goes like this: a scholar called Wang is attracted to a beautiful, homeless woman who claims to have escaped from a rich family who abused her. Wang gives her refuge, brings her home, and sleeps with her in his own studio. Later on, Wang meets a Taoist priest in the market. The priest tells Wang that he is bewitched by a nameless creature. Stirred by the words of the priest, Wang is curious, so one night, he sneaks into the mysterious woman's room and peeks through the window. The following is what he sees: 


\section{Excerpt Three from “Painted Skin” (畫皮)}

\section{Source text}

Minford's English translation

The $40^{\text {th }}$ tale, from volume 1: (Minford, 2006, p. 127):

躡跡而窗窺之, 見一獰鬼, 面翠色, 齒 Creeping stealthily up to a window, he 㭸㭸如鋸。鋪人皮於榻上，執彩筆而繪 之; 已而撙筆, 舉皮, 如振衣狀, 披於 身，遂化為女子。 peeped through and saw the most hideous sight, a green-faced monster, a ghoul with great jagged teeth like a saw, leaning over a human pelt, the skin of an entire human body, spread on the bed on his bed. The monster had a paintbrush in its hand and was in the process of touching up the skin in lifelike colour. When the painting was done, it threw down the brush, lifted up the skin, shook it out like a cloak and wrapped itself in it - whereupon it was instantly transformed into his pretty young 'fugitive' friend.

Frightened and disgusted by the genderless and nameless creature whom he has sexual intercourse with, Wang begs for help from the Taoist priest, but the priest only gives Wang his fly-blush and bides him to put it outside his bedroom. He thinks the fly-brush will be a warning to the creature. Yet the priest was wrong. He shouldn't have shown sympathy and compassion towards the monster. In the following night, the hungry monster tears the fly-brush into pieces, goes to Wang's bed, rips open his chest and tears his beating heart out. The Taoist priest is angry and he yells:

\section{Excerpt Four from “Painted Skin” (畫皮)}

\section{Source text}

\section{My English translation}

The $40^{\text {th }}$ tale, from volume 1 :

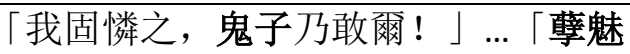

! 償我拂子來！」
"I had compassion on you; how dare you devil!"... "You base-born fiend! Give me my fly-brush!"

In the Chinese source text, Minford's English translation and my own translation, the creature is always genderless - it is “獰鬼” (an ugly ghost), “鬼子” (devil), and “菣鬼未” (base-born fiend). Pu Songling makes it obvious in the narrative that under the beautiful painted skin, the cannibalistic monster is a genderless but sexually attractive creature. The destabilization of gender boundaries is intriguing but dangerous, if not disturbing. 


\section{Gender Boundary Maintenance in Giles' "Painted Skin”}

The genderless demon disguised in a beautiful woman's skin is a witty parody of the imitative structures of gender. However, in Giles's English translation, the creature is no longer genderless; it is a female monster with a fixed gender. Throughout the English version of "Painted Skin", Giles uses the pronouns "she" and "her" many times to refer to the creature:

Excerpt Five from “Painted Skin” (畫皮)

\begin{tabular}{lll}
\hline $\begin{array}{l}\text { Source text } \\
\text { The } 40^{\text {th }} \text { tale, from volume }\end{array}$ & My English translation & $\begin{array}{l}\text { Giles' English translation } \\
\text { (Giles, 1880, p. 81) }\end{array}$ \\
\hline 「即是物矣。」 & \\
\hline
\end{tabular}

Now that the gender identity of the creature is clearly specified in Giles' version, gender ambiguity and queer erotic love are dismissed. The subversive notions suggested in the Chinese source texts are lost.

\section{Excerpt Six from “Painted Skin” (畫皮)}

\begin{tabular}{|c|c|c|}
\hline $\begin{array}{l}\text { Source text } \\
\text { The } 40^{\text {th }} \text { tale, from volume } \\
1:\end{array}$ & My English translation & $\begin{array}{l}\text { Giles' English translation } \\
\text { (Giles, 1880, p. 81) }\end{array}$ \\
\hline $\begin{array}{l}\text { 人皮劃然而脫; 化為厲 } \\
\text { 鬼, 臥嚊如豬。 }\end{array}$ & $\begin{array}{l}\text { The human skin dropped } \\
\text { off, and [it] became a } \\
\text { horrible ghoul, laying there } \\
\text { grunting like a pig. }\end{array}$ & $\begin{array}{l}\text { the human skin dropping } \\
\text { off, and she became a } \\
\text { hideous devil. There she } \\
\text { lay grunting like a pig. }\end{array}$ \\
\hline
\end{tabular}

In Giles' adaptation, this creature in Pu Songling's story becomes a Lilith-like female monster in the English translation. 'She' now conveniently and comfortably fits into the archetype of the monstrous-feminine - the beautiful, seductive, dangerous and evil figure that rebels against God, men, and the patriarchal structures. Pu Songling's tale is again hijacked by the sexist ideology.

\section{Conclusion}

In this paper, I have discussed the notions of free love, sexual freedom, and queer diversity explicitly expressed in Pu Songling's stories, which resonates with individualism and liberalism, "the twins in Western civilization" (Golden, 2006, p. 17). Yet, while the source text is meant to be potentially subversive, Giles' English translation in the late-Qing disappointingly distorts the original text and suppresses $\mathrm{Pu}$ Songling's subversive view on sex, love and marriage. The sexist ideology is 
perpetuated in the English target text. From this comparative study of the mid-Qing Chinese masterpiece and its late-Qing English translation, we can conclude that in the transitions of literature and culture, Western thoughts are not always 'modern'. 'New' gender views can be unearthed in old Chinese classics too. As explained in the introduction, the aim of this translation analysis is to demonstrate the importance of considering the cultural and contextual aspects in translation. The research study will be a meaningful one if Chinese learners of translation can understand the power of translation not only by practicing translation strategies, but also by recognizing how gender ideology can be naturalized and perpetuated through the translator's cultural manipulation of the target text.

\section{References}

Cheung, Y. (2014). When Classical Chinese Works Matter: A Critical Study of Pu Songling's Liaozhai Zhiyi and its English Translations. PhD thesis. Hong Kong: The University of Hong Kong.

Giles, A. H. (1880). Introduction. In H. A. Giles, Strange Stories from a Chinese Studio (xiii-xxxii). London: Thos. De la Rue.

Golden, S. (2006). The Modernisation of China and the Chinese Critique of Modernity. Revista HMiC: Història Moderna i Contemporània (4), 7-22. Retrieved from http://www.raco.cat/index.php/HMIC/article/viewFile/53271/61301

Lefevere, A. (1992). Translation, Rewriting and the Manipulation of Literary Frame. London, New York: Routledge.

Lin, K. (2002). Translation as a catalyst for social change in China. In M. Tymoczko \& E. Gentzler (Eds.), Translation and Power (160-183). Massachusetts: University of Massachusetts Press, 2002.

Liu, X. (2011). An Empirical Study for Translation Studies - A Multifaceted Perspective.

Translation Journal, 15(4). Retrieved from http://translationjournal.net/journal/58review.htm

Pu, S. (1880). Strange Stories from a Chinese Studio. (H. A. Giles, Trans.). London: T. De La Rue.

Pu, S. (2006). Strange Stories from a Chinese Studio. (J. Minford, Trans.). London: Penguin, 2006.

Qian, N. (2015). Politics, Poetics, and Gender in Late Qing China: Xue Shaohui and the Era of Reform. Stanford: Stanford University Press.

Tong, M. \& Minford, J. (1999). Whose Strange Stories?: P'u Sung-Ling (1640-1717), Herbert Giles (1845-1935), and the Liao-chai Chih-i. East Asian History, 17/18, 1-48. Retrieved from http://eastasianhistory.org/sites/default/files/article-content/17-18/EAH17-18 01.pdf

Wu, F. Y. (1987). The Gothic World of Foxes, Ghosts, Demons and Monsters: A Story of Liaozhai Zhiyi. PhD thesis. The University of Southern California.

Zhing, W. (2003). An Overview of Translation in China: Practice and Theory. Translation Journal, 7(1). Retrieved from http://translationjournal.net/journal/24china.htm 